\title{
The effect of natural and organophilic palygorskite on skin wound healing in rats
}

\author{
Mirna Luciano de Gois da Silva1,", Amanda Campos Fortes', Adriana da Rocha Tomé2, Edson \\ Cavalcanti da Silva Filho ${ }^{3}$, Rivelilson Mendes de Freitas ${ }^{1}$, José Lamartine Soares-Sobrinho ${ }^{4}$, Cleide \\ Maria da Silva Leite ${ }^{1}$, Mônica Felts de La Roca Soares ${ }^{4}$
}

\begin{abstract}
${ }^{1}$ Department of Biochemistry and Pharmacology, Federal University of Piaui, Teresina, PI, Brazil, ${ }^{2}$ Department of Veterinary Medicine, State University of Ceará, Fortaleza, CE, Brazil, ${ }^{3}$ Department of Chemistry, Federal University of Piaui, Teresina, PI, Brazil, ${ }^{4}$ Department of Pharmaceutical Sciences, Federal University of Pernambuco, Recife, PE, Brazil
\end{abstract}

\begin{abstract}
In view of growing interest in natural treatments, clays would appear to be a good alternative for speeding up the healing process during the treatment of wounds. Of the various clays, palygorskite, a clay from the Brazilian State of Piauí, composed of silicon and aluminum, has shown itself to be pharmaceutically useful as a healing agent. The aim of this article is to evaluate the effect on the healing of wounds of Piaui palygorskite, both in its natural state and when organophilic, by way of comparative analysis of macroscopic and histological tests on skin wounds in adult male and female two-month-old Wistar rats. To this end, a circular trichotomy of the dorsal cornus of the rats was carried out to confirm the effects of treatments involving $0.9 \%$ saline solution, collagenase, natural palygorskite, organophilic palygorskite with cetyltrimethylammonium chloride, and organophilic palygorskite with alkyldimethylbenzylammonium chloride. The testing of all the clays involved microbiological evaluation using the depth of plaque and surface striation methods, along with post-treatment macroscopic analysis of skin wounds by way of organoleptics, pachymetry and histological analysis. Microbiological evaluation revealed the need for sterilization of the clay prior to incorporation in the pharmaceutical form. Macroscopic analysis suggests that healing of the wounded area occurred, and histological analysis showed the beneficial effect of the topical use of clay material. Our data suggest that palygorskite may be more powerful than other healing agents, although, on completing treatment, all the animals studied showed the same degree of tissue repair.
\end{abstract}

Uniterms: Attapulgite/healing agent. Palygorskite/healing agent. Healing/experimental study. Skin wounds/healing/experimental study.

Devido ao crescente interesse da população pelos tratamentos naturais, as argilas representam uma boa alternativa para a aceleração da cicatrização durante o tratamento de feridas. Dentre as argilas, a paligorsquita, uma argila piauiense, devido à sua composição com silício e alumínio, demonstra certa aplicabilidade farmacêutica como agente cicatrizante. O objetivo deste artigo é avaliar a ação cicatrizante da paligorsquita piauiense em sua forma natural e organofilizadas por meio da análise comparativa da macroscopia e dos exames histológicos em feridas cutâneas de ratos machos e fêmeas Wistar adultos com 2 meses de idade. Para tanto, foram realizadas tricotomia circular no corno dorsal dos ratos para verificar os efeitos dos tratamentos realizados com solução salina $0,9 \%$, colagenase, paligorsquita natural, paligorsquita organofilizada por cloreto de cetiltrimetilamônio e paligorsquita organofilizada por cloreto de alquildimetilbenzilamônio. Para todas as argilas testadas foi feita a avaliação microbiológica pelo método de plaqueamento em profundidade e do método de estrias em superfície, bem como foi realizada após tratamento, a análise macroscópica das feridas cutâneas por meio organoléptico, medição em paquímetro e análise histológica. Por meio da avaliação microbiológica foi detectada a necessidade de esterilização da argila para posterior incorporação na forma farmacêutica. A análise macroscópica sugere que houve cicatrização da área lesionada, bem como a análise histológica demonstrou efeito benéfico após o uso tópico do material argiloso. Nossos dados sugerem que a paligorsquita pode exercer um maior

\footnotetext{
*Correspondence: M. L. de Gois da Silva. Programa de Posgraduação em Ciências Farmacêuticas, Universidade Federal do Piauí, 64049-550 - Teresina

- Piauí, Brasil. E-mail: mirnagois@yahoo.com.br
} 
efeito cicatrizante em relação aos demais tratamentos, embora após o término deste tratamento, todos os animais analisados apresentaram a mesma reparação tecidual.

Unitermos: Atapulgita/ação cicatrizante. Paligorsquita/ ação cicatrizante. Cicatrização/estudo experimental. Feridas cutâneas/cicatrização/estudo experimental.

\section{INTRODUCTION}

The healing of wounds, caused by the creation of discontinuities in body tissue through physical, chemical or mechanical processes, involves the migration of inflammatory cells, the synthesis of granulation tissue, the deposition of collagen and proteoglycans and the development of healing (Mendonça et al., 2006; Rocha Junior et al., 2006; Santos et al., 2002). However, in the initial stages of repair there may be difficulty with healing owing to increased edema and a reduction in the features of the cell responsible for this process (Carvalho et al., 2006).

In view of growing interest in natural treatments, clays may be considered a good alternative for speeding up healing during the treatment of wounds. Natural clays or clays modified by organophilization cause absorption, and formation and have anti-septic properties, because of the minerals they contain (Santos, 1992; Cara et al., 2000; Carretero, 2002).

Palygorskite (PALY) is a fibrous clay (Aguiar, Novaes, Guarino, 2002; Coelho, Santos, Santos, 2007a) belonging to the palygorskite-sepiolite group, characterized as a 2:1 layer phyllosilicate (tetrahedral: octahedral) (Reynolds, 1993). The octahedral sheets are continuous in one dimension and the tetrahedral sheets are divided in strip form by inversion. The apex oxygens pointing alternately upward and downward, in adjacent strips, are connected, resulting in a porous structure whose channels contain exchangeable cations and water molecules (Pereira Neto, Almeida, Carvalho, 1993).

PALY, extracted from a deposit located in the municipality of Guadalupe (PI-BRAZIL), has a greater proportion the oxides $\mathrm{SiO}_{2}, \mathrm{Al}_{2} \mathrm{O}_{3}, \mathrm{MgO}$ and $\mathrm{Fe}_{2} \mathrm{O}_{3}$ compared with other oxides having the formula $\left(\mathrm{Si}_{7.89}\right.$ $\left.\mathrm{A}_{10.11}\right)\left(\mathrm{Mg}_{1.81} \mathrm{Al}_{1.93} \mathrm{Fe}_{0.14} \mathrm{Ti}_{0.25} \mathrm{Mn}_{0.041} \mathrm{Cu}_{0.0059} \mathrm{Zn}_{0.005}\right)$ $\left(\mathrm{K}_{0.046}\right) \mathrm{O}_{20}(\mathrm{OH})_{2}\left(\mathrm{OH}_{2}\right) \cdot 4 \mathrm{H}_{2} \mathrm{O}$ (Silva et al, 2013). This composition suggests that the palygorskite has great potential in pharmaceuticals and cosmetics product. Given the presence of silicon, aluminum, iron, and magnesium, palygorskite is classified as a beige clay (a mixture of brown and white clay) (Souza, Antunes Junior, 2009; Silva et al., 2013). Moreover, PALY has a fibrous (three dimensional) clay structure, which does not allow the clay to swell through the expansion of the basal layers when exposed to water, as with lamellar crystalline silicates (Alexandre, Dubois, 2000; Silva et al., 2013).

Previous studies have described how the presence of silicon is extremely useful for medical and cosmetic purposes. The large quantities of this mineral in the clay suggest that it could play a crucial role in the reconstitution of skin tissue, and also provide greater rehydration and topical anti-inflammatory action (Bourgeois, 2006; Souza, Antunes Junior, 2009). Furthermore, the presence of aluminum suggests the use of the clay as a healing agent (Paiva, Morales, Díaz, 2008).

Many authors have reported that natural palygorskite, under Fourier transform infrared Spectroscopy, shows the presence of bands at 3,542 and 3,625 $\mathrm{cm}^{-1}$ which are characteristic of the stretching vibrations of $\mathrm{OH}$ groups relating to the hydroxyl on the surface of water contained in clay. Organoclays, also have spectra with similar absorption bands to those of natural clay and also has bands between $2,851 \mathrm{~cm}^{-1}$ and $2,921 \mathrm{~cm}^{-1}$, which are characteristic of oscillations of the connector $\mathrm{C}-\mathrm{H}$ band of the salts. These observations demonstrate that these have been incorporated into the clay, confirming the interaction with ammonium salts (Shen et al., 2005; Silva et al., 2013).

The organoclays are synthesized by the replacement of exchangeable cations present in the clay by organic cations of quaternary ammonium salts (cationic surfactants). The organophilization process thus intercalates surfactants between layers of the clay, altering not only the surface properties from hydrophilic to hydrophobic but also controlling a number of other properties, in particular colloidal and adsorbent ones (Kakegawa, Ogawa, 2002; Coelho, Santos, Santos, 2007b; Paiva, Morales, Díaz, 2008).

Palygorskite organophilizated with cationic ammonium salts releases water, as can be observed from the fact that in the DSC curves PALY-Natural does not appear beyond the higher limit of the temperature, i.e. $500{ }^{\circ} \mathrm{C}$. The salt apparently delays the degradation somewhat. However, these differences are not so significant compared with PALY-Natural. It can therefore be suggested that the organophilization process reduced the hydrophilic character of the clay in palygorskite. This favors the use of attapulgite in cosmetic products as it provides greater interaction with the skin (Silva et al., 2013). 
If clay is to be used for medicinal and cosmetic purposes, it must meet some physical, physico-chemical and microbiological requirements (Loyola, Nario, 2001). A stability study of the pharmaceutical and cosmetic forms containing clays is thus of fundamental importance for the safe use of these clay in humans.

The aim of this study is to evaluate the healing properties of Piaui palygorskite in its natural and organophillic forms in skin wounds in rats by way of comparative macroscopic analysis and histological examinations of different groups treated with natural and organophillic clay.

\section{MATERIAL AND METHODS}

The study was carried out in accordance with Brazilian Federal Law $n^{\circ}$ 6,638 of 1979 regarding Animal Experimentation, and approved by the UFPI's Animal Experimentation Ethics Committee (Protocol n ${ }^{0}$ 091/11).

\section{Preparation and microbiological control of the clays}

The palygorskite clay was provided by Mineração Coimbra Ltda (Guadalupe, Piauí, Brazil), and was used both in its natural form and in its organophilic derivative with alkyldimethylbenzylammonium chloride (BKC) and cetyltrimethylammonium chloride (CTAC) (Hester Química do Brasil Ltda).

Microbiological control of the clay was carried out using the depth of plaque (total viable micro-organism count - bacteria and fungi) and the surface striation method (research and identification of pathogens) according to the methodology described in Brazil (2010). After microbiological control, the samples were sterilized in an autoclave, under humid heat, for three one-hour cycles daily.

\section{Animals}

The study involved 50 two-month-old male and female Wistar rats with a mean body weight of $250 \mathrm{~g} \pm 50 \mathrm{~g}$. The animals were kept in appropriate polypropylene cages containing sterilized wood shavings, feed and water ad libitum, at a temperature of $26 \pm 1{ }^{\circ} \mathrm{C}$. The animals were divided randomly into 5 groups, according to the treatment to be carried out, making a total of ten rats per group (Table I).

\section{Acquisition and treatment of wounds}

After anesthesia and intramuscular relaxation of the rats using xylazine $(0.04 \mathrm{~mL} / 100 \mathrm{~g}$ of body weight $)$
TABLE I - Distribution of experimental groups for evaluation of skin wounds in rats

\begin{tabular}{ll}
\hline Groups $(\mathbf{n}=\mathbf{1 0})$ & Treatments \\
\hline AF & Physiological serum \\
BF & Collagenase \\
CF & PALY - Natural \\
D1F & PALY - CTAC \\
D2F & PALY - BKC \\
\hline
\end{tabular}

Key: AF - negative control, $\mathrm{BF}$ - positive control, $\mathrm{CF}-$ natural palygorskite, D1F - organophilic palygorskite with cetyltrimethylammonium chloride, D2F - organophilic palygorskite with alkyldimethylbenzylammonium chloride, $\mathrm{F}$ - wound.

and ketamine hydrochloride $10 \%(0.08 \mathrm{~mL} / 100 \mathrm{~g}$ of body weight), intraperitoneally (ip), each animal was placed over a surgical plank, in ventral decubitus and immobilized with tape for epilation and trichotomy of the dorsal region, which were carried out by way of removal of a circle of skin of around $0.4 \mathrm{~mm}$ in diameter with the aid of an electric punch, in order to expose the dorsal fascia muscles.

The topical treatment for each group was applied to the injured area, always at the same time of day $(8 \mathrm{~h} 00 \mathrm{am})$ with the products designed for each group and was observed daily after 7, 14 and 21 days of treatment (Santos et al., 2002; Rahal et al., 2001). Furthermore, to avoid cross-infection of wounds, sterilization was carried out daily, using an autoclave to sterilize the wood sawdust.

\section{Macroscopic evaluation of skin wounds in rats}

The animals treated with the main active ingredients under analysis were accompanied daily by way of observation of the healing of the wound, with reference to alterations with or without edema, the exudate, rust and coloration of the wound. A digital photographic record of the wounds of all the animals in the experiment groups was put together during treatment. The wounds were also measured with the aid of an analogical pachymeter after 7,14 and 21 days of treatment.

\section{Histological evaluation of skin wounds in rats}

A $0.5 \mathrm{~cm} \times 2.0 \mathrm{~cm}$ rectangular fragment of dorsal skin was removed from each animal after 7, 14 and 21 days of treatment, each segment comprising a central injured area and an uninjured peripheral area of skin to serve as a control (Herrmann, Woodward, Pulaski, 1964). All the skin wound samples obtained were fixed for $72 \mathrm{~h}$ 
in $10 \%$ formaldehyde, colored with hematoxylin and eosin (HE) and submitted to histological analysis at the State University of Ceará (UECE). The slides were scanned under a 40x optical microscope, always from left to right and top to bottom, with a view to detecting the presence or not of inflammation or healing processes using parameters relating to the presence in tissue of granulation, vascular proliferation, acute and chronic inflammation, the presence of collagen and re-epithalization.

\section{Statistical analyses}

The data were analyzed using GraphPad Prism Version 5.0 and expressed as the significant differences in healing effects regarding the means of the groups at start of treatment and after 7, 14 and 21 days, using Analysis of Variance, with $\mathrm{p} \leq 0.05$.

\section{RESULTS AND DISCUSSION}

\section{Microbiological control of palygorskite clay}

The microbiological evaluation of non-sterile attapulgite using the depth of plaque method showed the microbial load present, and the surface striations method revealed the presence of $E$. coli and $P$. aeruginosa. These results show that the clays need to be sterilized, since they may be contaminated to the extent that there is an impact in terms of loss of efficacy of treatment (Pinto, Kaneco, Ohara, 2000). In view of this, we used these methods comparatively on sterile clay and found a considerable reduction in the presence of micro-organisms.

\section{Macroscopic evaluation of skin wounds in rats}

Macroscopic analysis of the treatment, using physiological serum (negative control), collagenase (positive control) and natural and organophilic palygorskite on the skin wounds of rats indicated evolution towards repair of the tissue in the wounded area, with the presence of hemorrhaging only in the group treated with physiological serum on the 7 th day of treatment, characterized by an intensive inflammatory process, which causes damage through micro-circulation and inhibition of cell proliferation (Lucena et al., 2006).

The wounds were yellowish brown in color in the groups treated with BKC and CTAC organophilic palygorskite during the first week and reddish in the other groups. On subsequent days, effective healing of the wounds occurred. Apart from this, the experimental groups showed an absence of edemas and the presence of moderate or intense inflammatory exudate and these findings were confirmed by histological analysis with the presence of lymphocytes. The formation of a crust was observed at the end of the first week of evaluation of the groups treated with collagenase and natural and organophilic PALY, with the lesions evolving in the course of the treatment, thus corroborating the findings of Garros and colleagues (2006) (Figure 1).

Analysis of the diameter of the skin wounds in the treated rats (Figure 2), carried out using an analogical pachymeter showed that there was a significant difference between the groups treated with clay on the 7 th day of treatment, with the best results in the D2F group $(p<0.05)$, probably owing to the intense proliferation of fibroblasts, as confirmed by histological studies, resulting in the formation of more extensive crusts, thereby influencing the diameter of the wound scar.

With regard to the evolution of the wound, on the $14^{\text {th }}$ day subsequent to the operation, the animals in groups $\mathrm{AF}, \mathrm{BF}, \mathrm{CF}, \mathrm{D} 1 \mathrm{~F}$ and D2F had means $(\mathrm{mm})$ and standard deviations for the contraction rate of $2 \pm 0.72,1 \pm 0.52$, $1.3 \pm 0.34,2 \pm 0.57$ and $0.6 \pm 0.43$, respectively. As of that period, there was a gradual increase in contraction of the lesions (Figure 2).

Statistical analysis of the data show that, in the 14-day period subsequent to the operation, the average rate of wound contraction was significantly higher ( $\mathrm{p}$ $<0.05$ ) in the D1F group (treated topically with clay organophilizated by CTAC ) compared to other groups. No significant difference was found between the means for rates of wound contraction in the groups involved in this research 14 days after surgery. In short, these results demonstrate that the D1F group was more effective at tissue repair over 14 days. Considering this and the histological analysis, it is suggested that a further organophilization with ammonium salts be carried out using lower concentrations than those employed in the present study, in order to reduce toxicity.

\section{Histological evaluation of skin wounds in rats}

Histological analysis of the skin wounds in the rats treated in this study, carried out to characterize them for the presence of granulation tissue, vascular proliferation, acute and chronic inflammation, the presence of collagen, and re-epithalization (Marchini, 1994 apud Santos et al., 2006), showed that treatment with clay aided the healing process, even though the organophilic clays had toxic properties.

The days chosen for histological evaluation were based on studies by Herrmann and colleagues (1964) in which histological events in the healing process were 


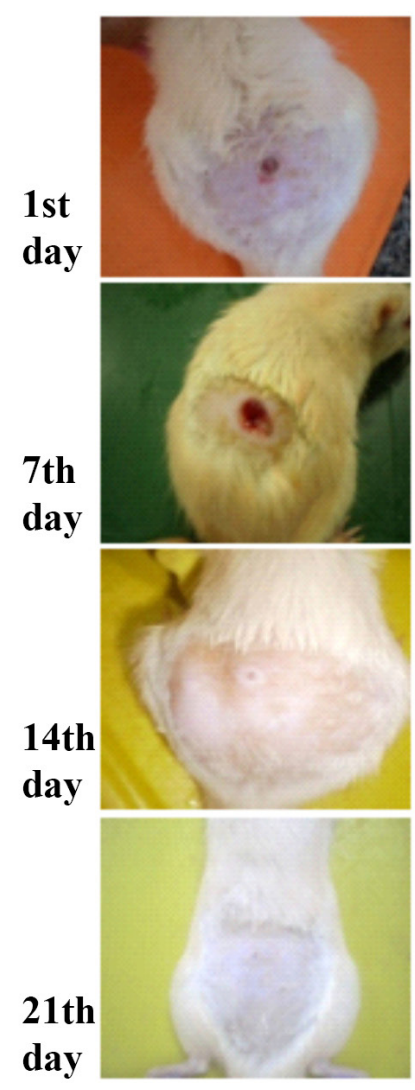

AF
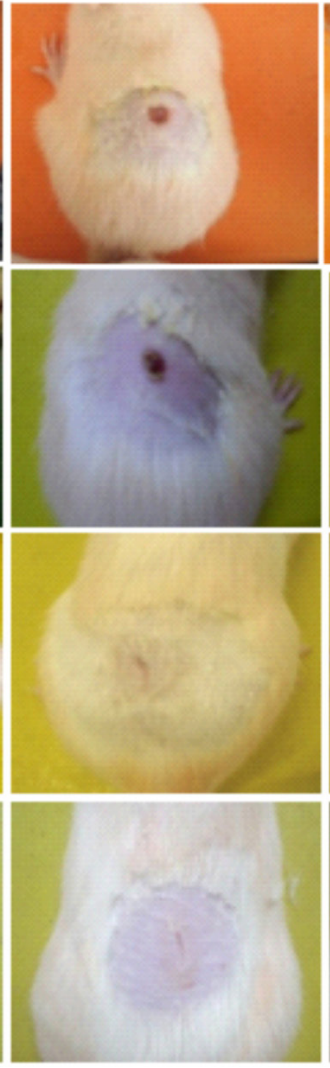

BF
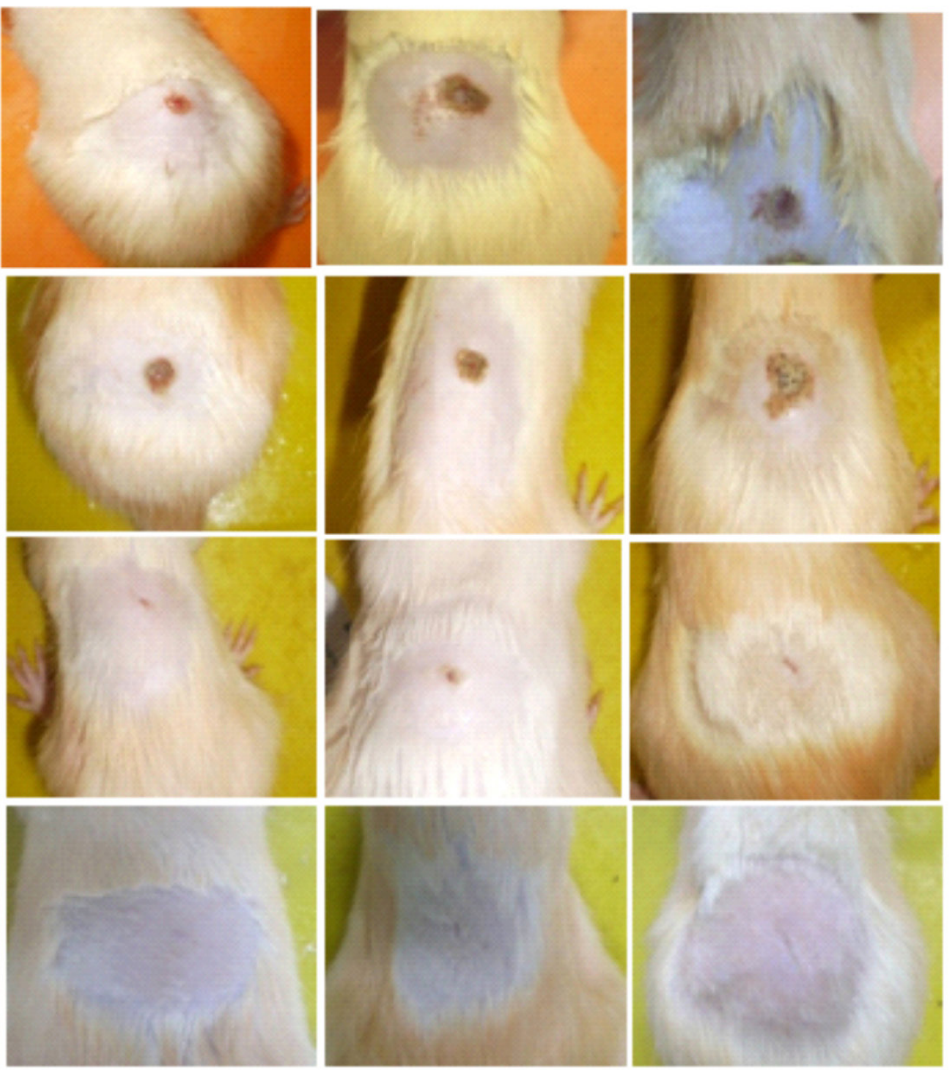

D1F

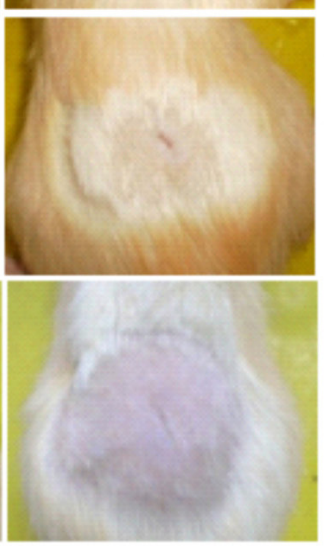

D2F

FIGURE 1 - Macroscopic analysis of cutaneous lesions of animals after 1, 7, 14 and 21 days of daily treatment. Key: Treatment groups: $\mathrm{AF}$ - physiological serum, $\mathrm{BF}$ - collagenase, $\mathrm{CF}$ - natural palygorskite, $\mathrm{D} 1 \mathrm{~F}$ - organophilic palygorskite with cetyl trimethyl ammonium chloride, D2F - organophylic palygorskite with alkyl dimethyl benzyl ammonium chloride, F - wound.

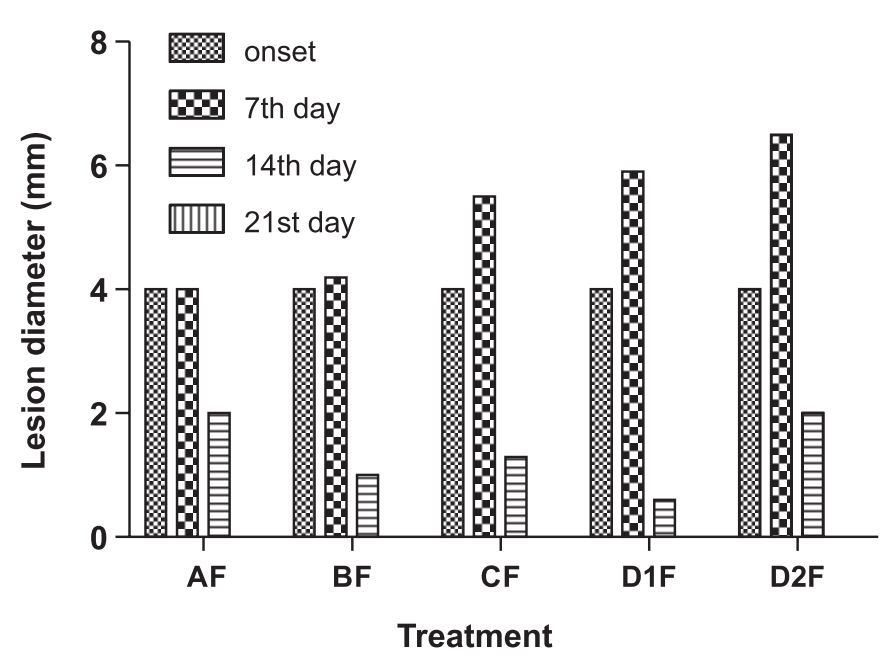

FIGURE 2 - Diameter of skin wounds in animals at the start of treatment and after 7, 14 and 21 days. Key: AF: physiological serum; BF: collagenase; CF: natural palygorskite; D1F: organophilic palygorskite with alkyldimethylbenzylammonium chloride; D2F: organophilic palygorskite with alkyldimethylbenzylammonium chloride. ${ }^{*} \mathrm{p} \leq 0.05$. shown to take place in three distinct phases. On the seventh day of treatment of skin wounds in rats (Figure 3), discreet to intense inflammatory exudation was observed, with a predominance of lymphocytes, which, according to Gartner; Hiatt (2007) may be involved in immune responses, with the count rising in locations that are infected or inflamed. This was observed in groups AF, BF, $\mathrm{D} 1 \mathrm{~F}$ and D2F, most intensely in the latter, probably because of vascular congestion, a factor suggesting toxicity, and which, consequently, stimulates the intense proliferation of fibroblasts and angiogenesis, which are also responsible for the secretion of collagen and the formation of blood vessels from pre-existing ones, respectively. However, group CF had a slight inflammatory infiltrate, as well as the reorganization of collagen in the presence of the proliferation of fibroblasts.

Figure 4 shows the results obtained on the 14th day of treatment of skin wounds. In all groups, except treatment group D2F, re-epithelization of the injured area was found, with an absence of dermic papillae and pilous follicles (Group AF); the presence of discrete and 
moderate dermic papillae, but without the formation of pilous follicles (Groups BF and D1F); and the presence
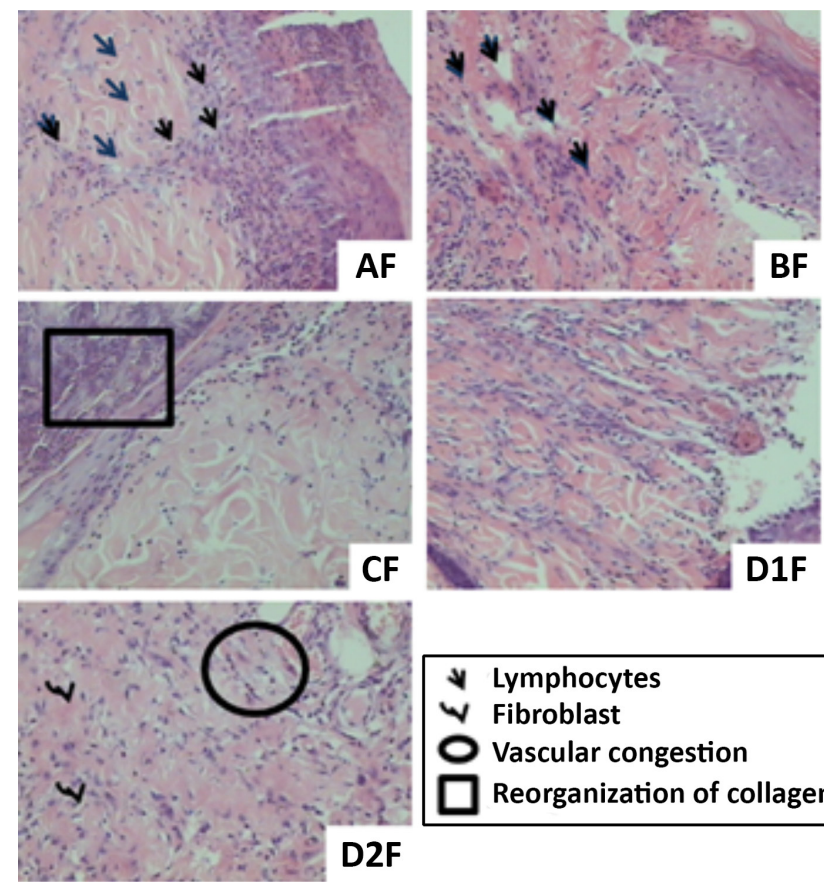

FIGURE 3 - Histological analysis of 7th day of treatment of skin wounds in rats. Key: AF - physiological serum, BF - collagenase, CF - natural PALY, D1F - PALY-CTAC, D2F PALY-BKC, F - wound.
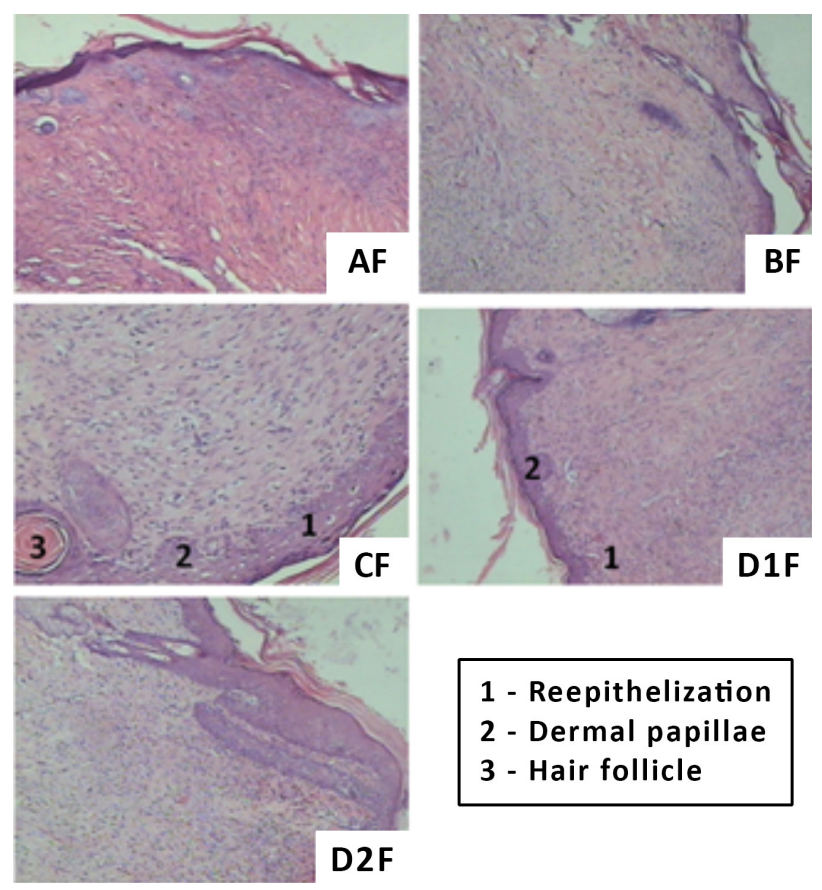

1 - Reepithelization

2 - Dermal papillae

3 - Hair follicle

FIGURE 4 - Histological analysis of 14th day of treatment of skin wounds in rats. Key: AF - physiological serum, BF - collagenase, CF - natural PALY, D1F - PALY-CTAC, D2F PALY-BKC, F - wound. of dermic papillae and pilous follicles (Group CF). Apart from this, slight lymphocyte infiltration (negative control) provided evidence of the probable efficacy of treatment using clays, even though their organophillic form leads to the proliferation of fibroblasts with a moderate number of fibrocytes (D1F) and moderate vascular congestion (D2F), but not lymphocyte infiltration.

The final (mature) phase in the process of tissue repair is characterized by endothelial regression (Garros et al., 2006). In the course of 21 days the continuous process of re-epithelization of the injured region was observed in all groups, with subsequent keratinization, giving rise to a corneal layer basically composed of keratin, a protein that is responsible for weather-proofing the skin (Gartner, Hiatt, 2007). Apart from this, there was a predominance of fibrocytes over fibroblasts, providing evidence of lower levels of synthesis of proteins, with the absence of necrosis, congestion and edema (Figure 5). These results corroborate those of studies conducted by Kuzu and colleagues (1998) and Wendler (1995), which found complete closure of the skin wound.

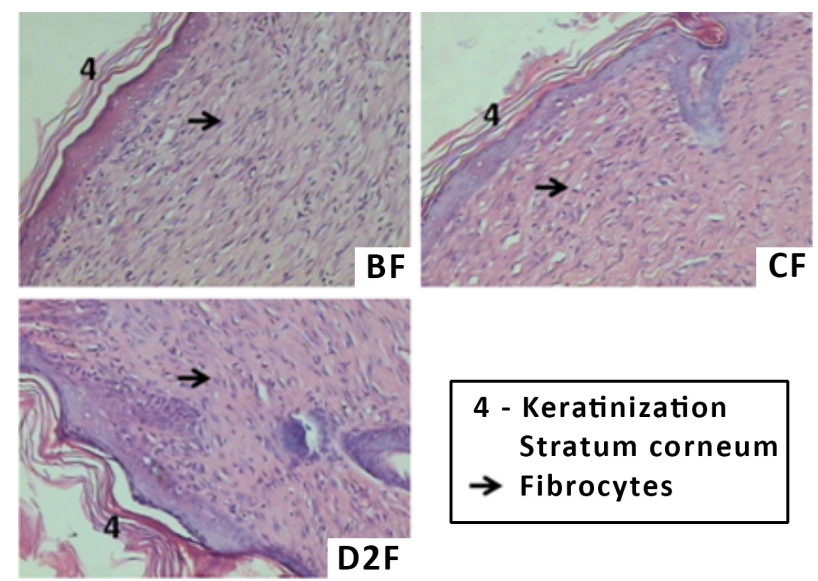

FIGURE 5 - Histological analysis on 21st day of treatment of skin wounds in rats. Key: BF - collagenase, $\mathrm{CF}$ - natural PALY, D2F - PALY-BKC, F - wound.

\section{CONCLUSION}

The topical use of Piauí palygorskite clay requires prior sterilization using an autoclave, in three one-hour cycles, owing to the presence of micro-organisms, as identified by microbiological analysis, which may have altered the functioning of the samples. Furthermore, clays in their natural form and organophillic clays can be shown, through macroscopic and histological analysis of skin wounds in rats, to give rise to the healing of lesions, with a better performance observed with natural palygorskite, as detected by reorganization of the collagen 
and the formation of blood vessels as of the seventh day of treatment, as well as the reoccurrence of re-epithalization, dermic papillae and pilous follicles as of the 14th day. The organophilic clays, despite good results, were toxic when healing wounds, as evidenced by the presence of vascular congestion and consequent increased proliferation of fibroblasts and collagen.

\section{ACKNOWLEDGMENTS}

We would like to thank Hester Química do Brasil Ltda for providing the quaternary ammonium salts; Mineração Coimbra Ltda for providing the clay; and the Federal University of Ceará for the histological analyses.

\section{REFERENCES}

AGUIAR, M.R.M.P.; NOVAES, A.C.; GUARINO, A.W.S. Remoção de metais pesados de efluentes industriais por aluminossilicatos. Quím. Nova, v.25, n.6B, p.1145-1154, 2002.

ALEXANDRE, M.; DUBOIS, P. Polymer-layered silicate nanocomposites: preparation, properties and uses of a new class of materials. Mater. Sci. Eng., R, v.28, n.1-2, p.1-63, 2000 .

BOURGEOIS, P. El extraordinario poder curativo de la arcilla. Barcelona: De Vicchi, 2006. 85 p.

FARMACOPÉIA Brasileira. 5.ed. Brasília: Anvisa, 2010. 836 p.

CARA, S.; CARCANGIU, G.; PADALINO, G.; PALOMBA, M.; TAMANINI, M. The Bentonites in pelotherapy: chemical, mineralogical and technological properties of materials from Sardinia deposits (Italy). Appl. Clay Sci., v.16, n.1, p.117-124, 2000.

CARRETERO, M.L. Clay minerals and their beneficial effects upon human health: a review. Appl. Clay Sci., v.21, n.3-4, p.155-163, 2002.

CARVALHO, P.T.C.; MAZZER, N.; REIS, F.A.; BELCHIOR, A.C.G.; SILVA, I.S. Analysis of the influence of low-power $\mathrm{HeNe}$ laser on the healing of skin wounds in diabetic and non-diabetic rats. Acta Cir. Bras., v.21, n.3, p.177-183, 2006.

COELHO, A.C.V.; SANTOS, P.S.; SANTOS, H.S. Argilas especiais: o que são, caracterização e propriedades. Quím. Nova, v.30, n.1, p.146-152, 2007a.
COELHO, A.C.V.; SANTOS, P.S.; SANTOS, H.S. Argilas especiais: argilas quimicamente modificadas - uma revisão. Quím. Nova, v.30, n.5, p.1282-1294, 2007 b.

GARROS, I.C.; CAMPOS, A.C.L.; TÂMBARA, E.M.; TENÓRIO, S.B.; TORRES, O.J.M.; AGULHAM, M.A.; ARAÚJO, A.C.F.; SANTIS-ISOLAN, P.M.B.; OLIVEIRA, R.M.; ARRUDA, E.C.M. Extrato de Passiflora edulis na cicatrização de feridas cutâneas abertas em ratos: estudo morfológico e histológico. Acta Cir. Bras., v.21, suppl.3, p.55-66, 2006.

GARTNER, L.P.; HIATT, J.L. Atlas colorido de histologia. 4.ed. Rio de Janeiro: Guanabara Koogan, 2007. 432 p.

HERRMANN, J.B.; WOODWARD, S.C.; PULASKI, E.J. Healing of colonic anastomoses in rat. Surg., Gynecol. Obstet., v.119, n.2, p.269-275, 1964.

KAKEGAWA, N.; OGAWA, M. The intercalation of $\beta$-carotene into the organophilic interlayer space of dialkyldimethylammonium-montmorillonites. Appl. Clay Sci., v.22, n.3, p.137-144, 2002.

KUZU, M.A.; KÖKSOY, C.; KALE, T.; DEMIRPENÇE, E.; RENDA, N. Experimental study of the effect of preoperative 5 -fluorouracil on the integrity of colonic anastomoses. $\mathrm{Br}$. J. Surg., v.85, n.2, p.236-239, 1998.

LOYOLA, M.P.; NARIO, S.R.S. Utilización de recursos termales en la búsqueda de salud y belleza. Rev. Cubana Farm., v.35, n.3, p.207-210, 2001.

LUCENA, P.L.H.; JURANDIR-FILHO, M.R.; MAZZA, M.; CZECZKO, N.G.; DIETZ, U.A.; CORREA-NETO, M.A.; HENRIQUES, G.S.; SANTOS, O.J.; CESCHIN, A.P.; THIELE, E.S. Avaliação da ação da Aroeira (Schinus terebinthifolius Raddi) na cicatrização de feridas cirúrgicas em bexiga de ratos. Acta Cir. Bras., v.21, suppl.2, p.46-51, 2006.

MENDONÇA, A.C.; FERREIRA, A.S.; BARBIERI, C.H.; THOMAZINE, J.A.; MAZZER, N. Efeitos do ultra-som pulsado de baixa intensidade sobre a cicatrização por segunda intenção de lesões cutâneas totais em ratos. Acta Ortop. Bras., v.14, n.3, p.152-157, 2006.

PAIVA, L.B.; MORALES, A.R.; DÍAZ, F.R.V. Argilas organofílicas: características, metodologias de preparação, compostos de intercalação e técnicas de caracterização. Cerâmica, v.54, n.330, p.213-226, 2008. 
PEREIRA NETO, J.; ALMEIDA, S.L.M.; CARVALHO, R.M. Atapulgita do Piaui para a indústria farmacêutica. Rio de Janeiro: CETEM/CNPQ, 1993. 22p. (Série Tecnologia Mineral; 64).

PINTO, T.J.A.; KANECO, M.T.; OHARA M.T. Controle biológico de qualidade de produtos farmacêuticos, correlatos e cosméticos. São Paulo: Atheneu, 2000. p.79-95.

RAHAL, S.C.; ROCHA, N.S.; BLESSA, E.P.; IWABE, S.; CROCCI, A.J. Pomada orgânica natural ou solução salina isotônica no tratamento de feridas limpas induzidas em ratos. Ciênc. Rural, v.31, n.6, p.1007-1011, 2001.

REYNOLDS, J.E.F. (Ed.). Martindale: the extra pharmacopoeia. 30.ed. London: Pharmaceutical Press, 1993. 1146 p.

ROCHA JUNIOR, A.M.; OLIVEIRA, R.G.; FARIAS, R.E.; ANDRADE, L.C.F.; AARESTRUP, F.M. Modulação da proliferação fibroblástica e da resposta inflamatória pela terapia a laser de baixa intensidade no processo de reparo tecidual. An. Bras. Dermatol., v.81, n.2, p.150-156, 2006.

SANTOS, P.S. Ciência e tecnologia de argilas. 2.ed. São Paulo: Edgard Blucher, 1992. 234 p.

SANTOS, L.O.M.; SIMÕES, M.L.P.B.; MACHADO, A.P.B.; MATIOSKI-FILHO, G.R.; ENDO, P.C.; GRUEN, G.R.; CIPRIANI, V.R.; MESQUITA, L.D. Efeito da somatotropina sobre a cicatrização de feridas cutâneas, em ratos. Acta Cir. Bras., v.17, n.4, p.220-224, 2002.
SANTOS, M.F.S.; CZECZKO, N.G.; NASSIF, P.A.N.; RIBASFILHO, J.M.; ALENCAR, B.L.F.; MALAFAIA, O.; RIBAS, C.A.P.M.; TRAUTWEIN, V.M.; HENRIQUES, G.S.; MAIA, J.M.A.; BITTENCOURT, R.C.A.Avaliação do uso do extrato bruto de Jatropha gossypiifolia L. na cicatrização de feridas cutâneas em ratos. Acta Cir. Bras., v.21, suppl.3, p.2-7, 2006.

SHEN, L.; LIN, Y.; DU, Q.; ZHONG, W.; YANG, Y. Preparation and rheology of polyamide-6/attapulgite nanocomposites and studies on their percolated structure. Polymer, v.46, n.15, p.5758-5766, 2005.

SILVA, M.L.G.; FORTES, A.C.; OLIVEIRA, M.E.R.; FREITAS, R.M.; SILVA-FILHO, E.C.; SOARES, M.F.R.; SOARES-SOBRINHO, J.L.; LEITE, C.M.S. Palygorskite organophilic for dermopharmaceutical application. $J$. Therm. Anal. Calorim., 2013. doi:10.1007/s10973-0122891-4

SOUZA, V.M.; ANTUNES-JUNIOR, D. Ativos dermatológicos: guia de ativos dermatológicos utilizados na farmácia de manipulação para médicos e farmacêuticos. 5.ed. São Paulo: Pharmabooks, 2009. 640 p. [Edição especial; v.1-4].

WENDLER, L.E. Estudo experimental comparativo da cicatrização de suturas jejunoileais em cães, utilizando o fio de poliglecaprone 25. Curitiba, 1995. 78 p. [Thesis of PhD degree. Faculdade Evangélica de Medicina do Paraná].

Received for publication on $14^{\text {th }}$ November 2012 Accepted for publication on $16^{\text {th }}$ September 2013 